\title{
Perceived impacts of woody encroachment on ecosystem services in Hluhluwe, South Africa
}

\author{
Linda Luvuno $^{1}{ }^{1} \underline{\text { Reinette Biggs }}^{1,2}, \underline{\text { Nicola Stevens }}^{3,4}$ and Karen Esler $^{5}$
}

\begin{abstract}
Anticipating, avoiding, and managing disruptive environmental change such as regime shifts and the impacts it has on human well-being is a key sustainability challenge. Woody encroachment is a globally important example of a regime shift that occurs in savanna systems, where a large fraction of the world's poor live. Woody encroachment is known to negatively impact a variety of ecosystem services, but few studies have investigated the impact of woody encroachment on local land users and their livelihoods. In this study, we conducted semi-structured interviews to determine how different land users-local subsistence communities and managers of conservation tourism areas-perceive woody encroachment in the Hluhluwe region of South Africa, how it affects the ecosystem services they rely upon, and what costs they incur in undertaking activities to reverse woody encroachment. Most interviewees perceived trees to be increasing in the landscape (83\%). However, perceptions about the causes of woody encroachment differed: community members cited the reduced usage of trees as the reason for woody encroachment, whereas conservation managers mostly attributed the change to increased $\mathrm{CO}_{2}$. Most community members felt woody encroachment was harmful to their household and general wellbeing, citing loss of grazing for livestock, and fear of attacks by wild animals and criminals as the main impacts. In contrast, conservation managers perceived woody encroachment to have both harmful and beneficial impacts, with the main negative impacts being loss of grazing for wildlife and impacts on tourism through reduced visibility for game viewing. All the conservation areas invested in tree clearing compared to only $20 \%$ of respondents in the community areas, where an average of ZAR367 (US\$25) was spent per year on clearing, compared to ZAR293,751 (US\$20,000) and ZAR163,000 (US\$11,000) spent in private game reserves and government reserves, respectively. Our findings highlight the negative impacts of ongoing woody encroachment, the differentiated impacts it has on different land users, and differences in capacity to combat encroachment. These findings highlight the need for state-funded management interventions to support clearing of trees in encroached areas, particularly in communal areas.
\end{abstract}

Key Words: communities; conservation; human well-being; regime shifts; savanna; social-ecological systems

\section{INTRODUCTION}

One of the five grand challenges for earth system and sustainability research is to better anticipate, avoid, and manage disruptive global environmental change such as regime shifts (Reid et al. 2010). Regime shifts are large and persistent changes in the structure and function of ecosystems and social-ecological systems (SES), and have been documented in a variety of aquatic and terrestrial systems (Scheffer et al. 2001, Biggs et al. 2018). They can significantly alter ecosystem services, as sets of species with particular traits, e.g., grasses, are replaced by species with fundamentally different traits, e.g., trees, which functionally provide different services (Loreau et al. 2001, Diaz et al. 2004, Cardinale et al. 2012). Regime shifts therefore typically lead to a reduction in some ecosystem services, although there may also be gains in other services (Troell et al. 2005, Grossman 2015, King et al. 2015, Ye et al. 2018). These changes affect human well-being by impacting the necessary materials for a good life, security, health, and social and cultural relations (Millennium Ecosystem Assessment 2005).

One globally important regime shift is woody tree and shrub encroachment in savannas. Savannas are mixed tree-grass systems that are characterized by a continuous grass layer and a discontinuous tree layer, and encroachment occurs when there is a shift from open grassy savannas to a persistently woody savanna (Daskin et al. 2016, Stevens et al. 2017, Luvuno et al. 2018). Savannas cover $20 \%$ of the earth's land surface and one fifth of humanity relies on the ecosystem services they provide (Sankaran et al. 2005, Lehmann et al. 2014). Encroachment is already extensively documented across many tropical savannas globally (Stevens et al. 2017). Woody encroachment results from a shift in the underlying feedback processes that suppress woody growth, and typically arises from the interplay between ecological and social processes such as rainfall, fire suppression, and grazing management (Luvuno et al. 2018, Wilcox et al. 2018, Liao et al. 2020). The most commonly cited drivers of woody encroachment are fire suppression and an increase in global carbon dioxide $\left(\mathrm{CO}_{2}\right)$ concentration, which enables trees to establish and grow faster than managers can successfully manage them with fire (Luvuno et al. 2018, Wilcox et al. 2018).

Woody encroachment can negatively impact ecosystem services, especially livestock grazing, crop production, biodiversity, and tourism (Briggs et al. 2005, Huxman et al. 2005, Eldridge et al. 2011, Archer and Predick 2014, Honda and Durigan 2016). As a result of these impacts, much effort has been invested to understand the drivers of woody encroachment and the associated impacts, especially on biodiversity and grazing capacity (Moustakas et al. 2010, Wigley et al. 2010, O'Connor et al. 2014, Stevens et al. 2016). However, few studies have investigated the impacts of woody encroachment on local land users and their livelihoods (examples include Mugasi et al. 2000, Wigley et al. 2009, Shackleton et al. 2013), and how this in turn influences ecosystem management strategies (Luvuno et al. 2018).

${ }^{1}$ Centre for Sustainability Transitions, Stellenbosch University, South Africa, ${ }^{2}$ Stockholm Resilience Centre, Stockholm University, Sweden, ${ }^{3}$ Department of Botany and Zoology, Stellenbosch University, South Africa, ${ }^{4}$ Environmental Change Institute, University of Oxford, United Kingdom, ${ }^{5}$ Department of Conservation Ecology and Entomology, Stellenbosch University, South Africa 
Fig. 1. Study site location: the Big 5-Hlabisa municipality in Kwazulu-Natal, South Africa.

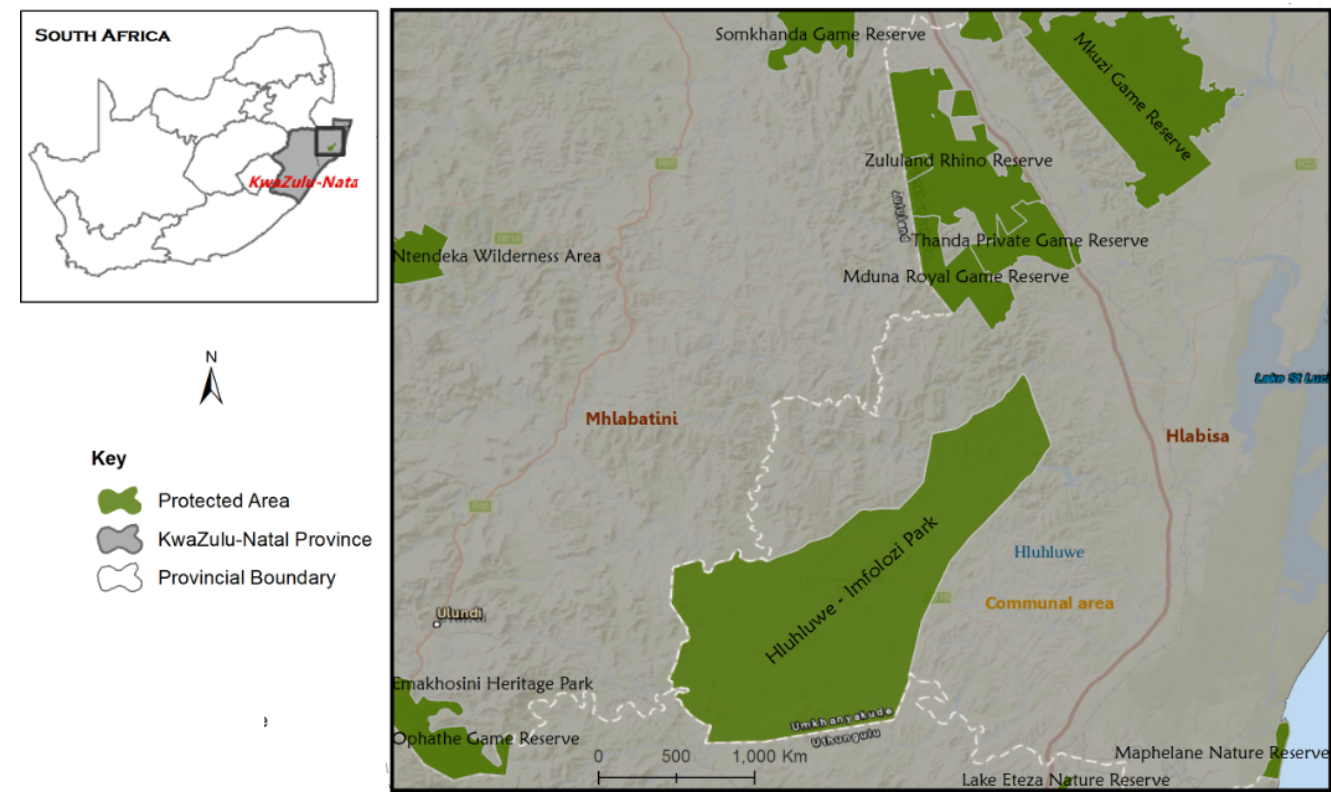

The need for a deeper understanding of how different land users perceive and rely on ecosystem services has been identified as a critical research priority (Carpenter et al. 2009, Wangai et al. 2016). This is particularly important for the rural poor in developing countries who often rely disproportionally on nature for their sustenance and livelihoods (McNally et al. 2016). Our research builds on the handful of studies on this issue in Africa to date, and contributes to addressing the much-needed gap in understanding the impacts of woody encroachment as perceived by different stakeholders with different interests and priorities (Wilcox et al. 2018, Liao et al. 2020).

The perspectives and needs of the rural poor are important considerations because their dependence on ecosystem services may foster priorities that are different to, for instance, tourism and conservation organizations (McNally et al. 2016). Ecosystem services are perceived differently by different land users, and land users are likely to respond differently to changes in ecosystem services because their land use and resources differ (Carpenter et al. 2009, Ellis et al. 2019). This diversity in perceptions and responses can be seen at multiple scales, e.g., household, village, and region, and responses at one scale may act synergistically with or in antagonism to responses at another scale (Leslie and McCabe 2013, Daw et al. 2015). For this reason, it is important to quantify the trade-offs and synergies among ecosystem services and how they affect different users, as well as their implications for local policies and management interventions (Daw et al. 2015). In many cases, interventions are implemented, but often fail, because they are implemented without consulting land users about their perceptions and needs (Menzel and Teng 2009, McNally et al. 2016).

We investigated the impacts of woody encroachment on ecosystem services as perceived by different land users-local subsistence communities and managers of conservation tourism areas - in the Hluhluwe area of South Africa. Hluhluwe lies within the savanna region, which is the dominant biome in South Africa and home to over 11 million people (Twine et al. 2003). It is one of the areas in South Africa that has recently undergone woody encroachment (Wigley et al. 2009) and has contrasting land uses existing side-by-side, providing a good context for comparing the effects of woody encroachment on different land users. It is well documented that rural communities in the savanna systems of South Africa supplement their livelihoods with natural resources, specifically wood for fuel and building materials, grass for thatching and brooms, and plant products for medicinal purposes (Lawes et al. 2004, Thondhlana et al. 2012, Hamann et al. 2015). South African savannas are also home to many of the country's most well-known conservation areas and support significant numbers of the world's remaining megafauna. Woody encroachment negatively affects game viewing, which impacts visitor numbers in reserves (Gray and Bond 2013). This study spanned a state-owned conservation area and adjacent communal areas that comprise mainly small-scale subsistence farming, and private game reserves. These were the key questions addressed by the study: (1) How do different land users perceive woody encroachment? (2) How does woody encroachment affect ecosystem services valued by different users? (3) What costs are different land users incurring to reverse woody encroachment?

\section{METHODS}

\section{Study area}

Hluhluwe lies in the Big 5-Hlabisa municipality of KwaZuluNatal, South Africa ( $28^{\circ} 0^{\prime} 00^{\prime \prime} \mathrm{S}$ to $28^{\circ} 0^{\prime} 0^{\prime \prime} \mathrm{S}$ and $32^{\circ} 0^{\prime} 00^{\prime \prime} \mathrm{E}$ to $32^{\circ} 34^{\prime} 48^{\prime \prime}$ E; Fig. 1). This area has undergone substantial woody encroachment in the last 70 years (Wigley et al. 2009). Mean annual precipitation (MAP) of the area ranges from $700 \mathrm{~mm}$ to $990 \mathrm{~mm}$ per annum, with most of the rainfall falling in the summer months of September to March. South African savannas falling in this rainfall range have experienced the highest rate of woody 
encroachment in the country (Skowno et al. 2017). Temperatures in the area are warm to hot, particularly during the summer months. Mean annual temperature is $22.5^{\circ} \mathrm{C}$, with a mean minimum July temperature of $13{ }^{\circ} \mathrm{C}$ and a mean maximum February temperature of $35^{\circ} \mathrm{C}$ (Wigley et al. 2009).

The Big 5-Hlabisa municipality is largely inhabited by Black Africans, who make up $99.4 \%$ of the total population, with $94 \%$ of the people speaking IsiZulu as a home language. Poverty is a major issue, as reflected by the high unemployment rate of $52.6 \%$, rising to $61.9 \%$ unemployment among the youth (StatsSA 2018). The level of education in Big 5-Hlabisa is relatively low: $14.7 \%$ of the population have no schooling, $31.2 \%$ have completed high school, 7.1\% have higher education qualifications, and the rest have some form of schooling (StatsSA 2018). Average household income ranges from ZAR19,600 (US\$1300) to ZAR38,200 (US\$2500), though some households have no income and others have an income of over ZAR300,000 (US\$19,000).

There are two main land uses in the municipality: subsistence agriculture on the communal lands, and conservation and tourism on national and privately owned game reserves. Communal lands are areas that are under traditional African tenure arrangements, where land is allocated by local Zulu chiefs and councils. Most of these areas are used for subsistence agriculture, and the inhabitants of these areas are heavily dependent on government grants and remittances from family members working in the cities (Kok and Collinson 2006, StatsSA 2018). The state-owned conservation area, Hluhluwe-iMfolozi Game Reserve, covers 98,000 ha and aims to ensure conservation and the sustainable use of the biodiversity under its jurisdiction. Hluhluwe-iMfolozi is one of South Africa's flagship game reserves and attracts around 200,000 visitors per year, generating a revenue of ZAR28 million (US\$1,850,000) per annum (Aylward and Lutz 2003). In the early 1900s, privately owned land was mainly used for commercial cattle farming. However, from the 1970s, many of the commercial farmers in the area changed from cattle farming to game farming (Wigley et al. 2009). Many of the commercial farms now form conglomerates of private game reserves with the objective of conserving local biodiversity, often for commercial gain through tourism activities and selling game (Higgins et al. 1999). The land in some of these private reserves, in part or fully, belongs to the community members surrounding them with the intention that benefits flow back to communities.

\section{Data collection}

Community members living in the communal lands, as well as conservation managers on the private and state-owned game reserves were interviewed using semi-structured questionnaires (Appendix 1,2). The interviews sought to gain insight into the interviewees' perceptions of what changes had occurred in the landscape, what caused these changes, and how it has impacted their lives. The interviews were also used to determine what the different land users are doing to counteract woody encroachment, and the cost of these activities. Interviews were conducted in Zulu or English depending on the interviewees' preferred language of communication; given that the lead researcher was fluent in both languages, no translators were needed.

Hluhluwe-iMfolozi Game Reserve is the only state conservation reserve in the area. It has six managers (one park manager and five section rangers), all of whom were interviewed. The small number of private game reserves in the area (each reserve has one manager) limited the number of private game reserve managers that could be interviewed. We were able to interview four private reserve managers out of the eight that we tried to contact. Collectively, these four managers manage over 70,000 ha. In the communal areas, household interviews were conducted with 30 community members from four villages, using a snowball sampling approach. Only people who had been living in the area for over 20 years were interviewed. This was mainly to exclude minors from the study and because woody encroachment in the area occurred 10-20 years prior to the inception of the study (Wigley et al. 2009). The interviewees were adults of a mixture of ages and genders, with different occupations and levels of education (Table 1).

Table 1. Demographics of the different land users interviewed.

\begin{tabular}{lcccl}
\hline \hline Land Users & Gender & $\begin{array}{c}\text { Mean Age } \\
\text { (years) }\end{array}$ & Ethnicity & $\begin{array}{l}\text { Mean } \\
\text { Education }\end{array}$ \\
\hline $\begin{array}{l}\text { Community } \\
\text { members } \\
\text { (n) }=30\end{array}$ & $63 \% \mathrm{~F}$ & $53.6 \pm 12.5$ & $100 \%$ Black & $\begin{array}{l}60 \% \text { grade } 10 \\
\text { or less }\end{array}$ \\
$\begin{array}{l}\text { State reserve } \\
\text { managers } \\
\text { (n) }=6\end{array}$ & $100 \% \mathrm{M}$ & $41.7 \pm 1.1$ & $83 \%$ Black & $\begin{array}{l}67 \% \text { post } \\
\text { graduate }\end{array}$ \\
$\begin{array}{l}\text { Private reserve } \\
\text { managers } \\
\text { (n) }=4\end{array}$ & $50 \% \mathrm{~F}$ & $38 \pm 3.8$ & $100 \%$ White & $\begin{array}{l}100 \% \text { post } \\
\text { graduate }\end{array}$ \\
\hline
\end{tabular}

The interviews were conducted between February and March 2018 and were on average 45 minutes long. The interviews included a combination of closed and open-ended questions, allowing us to quantitatively assess certain aspects of change, while at the same time allowing the interviewees' perceptions and qualitative data to emerge. Separate questionnaires with similar questions were used for community members and reserve managers, given their different contexts (Appendix 1, 2). In both cases, the open-ended questions included questions related to the perceived causes, impacts, costs, and management of woody encroachment. The costs of encroachment were derived from a question asking about the total cost of woody encroachment management over the past year. The interviewer filled out the questionnaire during the interview, which was also digitally recorded. Participation was on a voluntary, confidential basis, and the research was approved by the Stellenbosch University Research Ethics Committee (CEE-2017-0200-247).

\section{Data analysis}

Each handwritten questionnaire was checked against the digitally recorded interview, transcribed, and the open questions were coded using a thematic analysis (Alhojailan 2012, Bree and Gallagher 2016). The number of times a theme was mentioned was tallied and tabulated for further analysis. Fisher's exact tests were employed on the aggregated coded data to examine differences between land user groups. Fisher's exact test is a test of significance that is used in the place of chi square when the sample size is small (Dai et al. 2007). The unavoidably small and unequal and sample sizes limited the power of the tests, and our results therefore focus on suggestive patterns rather than hard differences among groups. Examples of relevant quotes from interviewees are presented in the results section to illustrate the aggregated findings. 


\section{RESULTS}

\section{Perceptions of woody encroachment}

The majority of interviewees thought the number of trees in the landscape were increasing $(83 \%)$, and there were no significant differences in perception of the amount of woody encroachment between the different land users (Fig. 2). All the game reserve managers, on both the private and state-owned reserves, reported that woody encroachment is occurring in their reserves. Fifty percent of the community members said trees were increasing on their property, and $83 \%$ said trees were spreading in the area. Only $20 \%$ of the interviewed community members reported trees to have either decreased or remained constant.

Fig. 2. Land user responses regarding their perceptions of woody encroachment. Error bars depict $95 \%$ confidence intervals around the group means. Black lines are the average across land users. Response options included "yes" (depicted), "no," and "not sure."

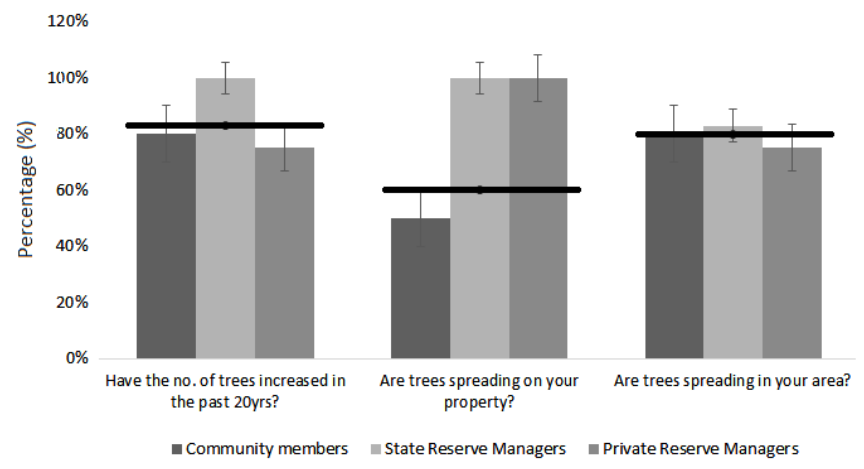

A list of perceived causes of encroachment was compiled based on the open-ended responses to the questionnaire (Table 2). Overall, across all user groups, people cited the reduced usage of trees as the reason for woody encroachment in the area. Community members thought reduced use (38\%) and deagrarianization $(46 \%)$ were the main causes of woody encroachment in the landscape. Some community members thought encroachment was indicative of natural regeneration processes, e.g., germination, related to rainfall (17\%). Notably, no community members attributed the increase in woody encroachment to increased $\mathrm{CO}_{2}$ levels in the atmosphere. In contrast, most of the reserve managers, both state and private, thought increased carbon dioxide, increased variability in droughts and floods, mismanagement of fire, and the historical legacy of cattle farming in the landscape were the main causes of the woody encroachment. Other causes mentioned by only the reserve managers were fragmentation of landscapes, overgrazing, and a lack of managerial expertise.

\section{Perceived impacts on ecosystem services}

Although there were no significant differences in how land users perceived the overall impact of woody encroachment (Fig. 3), analysis of the underlying narratives provided insight into the different types of impacts experienced by different users. Fiftyfour percent of community members thought woody encroachment was harmful to their household and general wellbeing. This was mainly attributed to the reduction of grass for grazing and increased fear of attacks by wild animals such as leopard and hyena (Table 3). Other notable impacts of woody encroachment mentioned were the reduction of water supply, increased fear of criminals who hide in the thick bushes, livestock getting lost in the bushes, and having to walk further because the bushes close walking paths. An example of these is illustrated in this quote: "There's nothing inherently wrong with trees but having a lot of trees uses more water. We need to sometimes cut down trees to get more water into the landscape. These thick areas hide wild animals such as leopard. Also, these trees kill grass and our livestock is life."

Table 2. Land user perceptions of the causes of woody encroachment (Fisher exact test: $\mathrm{X}^{2}=72.15$; $\mathrm{df}=24$; $\mathrm{p}<0.01$ ) Dash (-) indicates where a particular cause was not reported. Percentages were based on the frequency each item was mentioned in thematically coded open questions.

\begin{tabular}{lccc}
\hline \hline $\begin{array}{l}\text { Causes of woody } \\
\text { encroachment }\end{array}$ & $\begin{array}{c}\text { Community } \\
\text { members } \\
(\% ; \mathrm{n}=30)\end{array}$ & $\begin{array}{c}\text { State reserve } \\
\text { managers } \\
(\% ; \mathrm{n}=6)\end{array}$ & $\begin{array}{c}\text { Private } \\
\text { reserve } \\
\text { managers } \\
(\% ; \mathrm{n}=4)\end{array}$ \\
\hline Reduced tree use & 38 & 17 & - \\
Deagrarianization & 46 & - & - \\
Natural process & 17 & 17 & - \\
Increased carbon dioxide & - & 67 & 50 \\
Increased variability in & - & 67 & 50 \\
droughts and floods & - & 33 & 50 \\
Mismanagement of fire & - & - & 50 \\
Historical legacy & 8 & - & 25 \\
Don't know & 8 & 17 & - \\
Low game numbers & - & - & 25 \\
Fragmentation of landscapes & - & - & 25 \\
Overgrazing & - & - & 25 \\
Lack of managerial expertise & & &
\end{tabular}

Fig. 3. Land users' views on the impacts of woody encroachment. $\left(X^{2}=6.63 ; \mathrm{df}=6 ; \mathrm{p}=0.28\right)$

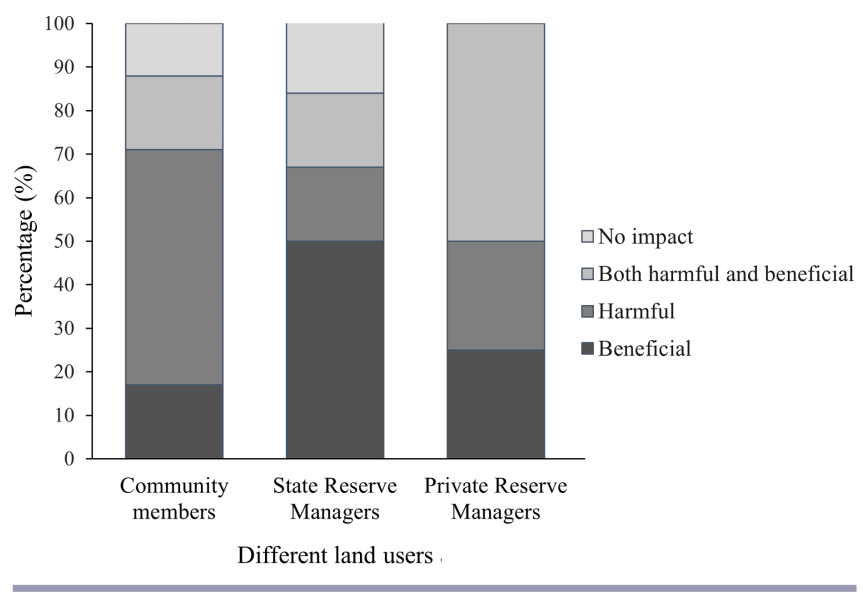

A few community members thought woody encroachment was both beneficial and harmful $(17 \%)$ or just beneficial $(17 \%)$. The most frequently reported benefit was firewood, even though $93 \%$ of the respondents reported a decreased use of trees over time, as for instance illustrated by this quote: "We used to use trees to 
build fences, houses, kraals, and for firewood. Now we use bricks, wire, and electricity." When asked how much firewood people collected, only $7 \%$ households reported that they still relied on firewood, spending an average of 21 hours per year collecting firewood, with no change in use over the years.

Table 3. Land user views of the harmful impacts of woody encroachment (Fisher exact test: $\mathrm{X}^{2}=25.31$, df $=18, \mathrm{p}=0.27$ ). Dash (-) refers to no reported impacts. Percentages were based on the frequency each item was mentioned in thematically coded open questions.

\begin{tabular}{lccc}
\hline \hline $\begin{array}{l}\text { Harmful impacts of woody } \\
\text { encroachment }\end{array}$ & $\begin{array}{c}\text { Community } \\
\text { members } \\
(\% ; \mathrm{n}= \\
30)\end{array}$ & $\begin{array}{c}\text { State } \\
\text { reserve } \\
\text { managers } \\
(\% ; \mathrm{n}=6)\end{array}$ & $\begin{array}{c}\text { Private reserve } \\
\text { managers } \\
(\% ; \mathrm{n}=4)\end{array}$ \\
\hline Reduces grass for grazing & 29 & 33 & 50 \\
Reduces water & 13 & 17 & 25 \\
Fear of wild animals \&/or & 25 & 33 & - \\
increased attacks by animals & 17 & 17 & - \\
Fear of criminals & 8 & - & 75 \\
Expensive to clear & 8 & - & - \\
Spreads invasive alien species & 13 & - & - \\
Livestock gets lost in the bushes & 17 & 17 & - \\
Closes walking paths & - & 17 & 50 \\
Replaces useful tree species & - & - & \\
Guests cannot see the game & & &
\end{tabular}

In contrast, woody encroachment was perceived to be beneficial by $50 \%$ of the state game reserve managers and $25 \%$ of the private game reserve managers, whereas a further $50 \%$ of the private game reserve managers thought woody encroachment was both harmful and beneficial (Fig. 3). State reserve managers reported the reduction of grass for grazing by game animals and the increased fear of wild animal attacks during patrols $(33 \%)$ as the main negative impacts of woody encroachment (Table 3). In private game reserves, the impacts of woody encroachment were mainly the high cost of clearing $(75 \%)$, complaints from the guests about not being able to see the game $(50 \%)$, and the loss of grazing potential $(50 \%)$. All the game reserve managers noted the beneficial impact of increased food for browsers and having a heterogeneous landscape, as for instance illustrated by this quote: "Some species, like the black rhino, like closed areas. So, it is good to have some woody areas."

\section{Management actions and costs}

There were significant differences in how woody encroachment was managed across the different land users (Table 4). A minority $(20 \%)$ of the respondents in the community cleared trees on their properties, and even fewer $(13 \%)$ cleared trees outside their property. Of the six community members who cleared trees on their property, they spent, on average, R367 (US\$25) on clearing in the previous year (2017). In contrast, in the game reserves, much effort goes into the management of woody encroachment, particularly in the private reserves. Private game reserves spent an average of R293,751 (US\$20,000) on woody encroachment management in the previous year, which consisted of both manual clearing and fire (Table 4). One of the reserves reported having spent an estimated R650,000 (US\$42,000) in the previous year on woody encroachment management. Most of the clearing on these reserves was focused on heavily encroached areas on the popular tourist routes, whereas the less travelled routes were seldom cleared because of the high costs. For example, one of the reserves specifically invested in clearing around their gate and toward the lodges so guests could see game as they enter their premises. The state game reserve spent R163,000 (US $\$ 11,000$ ) the previous year on burning the reserve as a measure to counteract woody encroachment. None of the reserves help clear or manage woody encroachment outside their reserves.

\section{DISCUSSION}

Most work examining the impact of woody encroachment on ecosystem services has focused on the biophysical and economic implications, without examining land user perceptions (Eldridge et al. 2011, Anadón et al. 2014, Wilcox et al. 2018). This study presents one of few efforts to understand perceptions around the drivers and impacts of woody encroachment, focusing on the Hluhluwe area of South Africa. Insight into land users' perspectives can guide the design and implementation of policies or programs that are consistent with the biophysical, social, and economic needs of the people living in these social-ecological systems (Menzel and Teng 2009, Liao et al. 2020).

Although we found that perceptions of the causes of woody encroachment varied, all land users generally perceived Hluhluwe to be much woodier now than in the past (Fig. 2). This is consistent with reports of woody encroachment occurring in the area and around the world (Wigley et al. 2009, Stevens et al. 2017). However, perceptions around the underlying cause of woody encroachment differed. The differences in perceptions may be linked to different education levels between the land users. All the reserve managers who mentioned climate change, variability of droughts and floods, and the mismanagement of fire had postgraduate degrees in a conservation-related field. Some of the state managers who did not study conservation did not mention these as possible causes, and neither did any of the community members. Interestingly, only one of the reserve managers cited reduced use as a cause of woody encroachment, although this along with deagrarianization were the main causes perceived by community members. Of course, all these processes are likely interacting and resulting in varying densities of woody encroachment, with some drivers more important in some areas (Luvuno et al. 2018). However, these stark differences in perceived drivers inform very different management policies and programs, and their perceived appropriateness and potential support by different land users.

Our results further indicate that different land users agreed that woody encroachment has a variety of mostly harmful impacts on their livelihoods, well-being, and businesses. Impacts on grazing were a key impact perceived by all land users. In the communal areas of Hluhluwe, loss of grazing primarily impacts cattle. Cattle in rural communities have multiple purposes and their importance to people's livelihoods is captured in the phrase "our livestock is life." Some of the goods and services provided by cattle include cash sales, providing a savings value, food, manure, and being slaughtered for cultural rituals (Shackleton et al. 2005). Other key impacts perceived by community members in our study included fear of criminals hiding in the thick vegetation and closure of walking paths. These findings align with insights from one of the few similar research studies in another part of South Africa, where a rural community had negative attitudes toward woody 
Table 4. Management of bush encroachment by different land users (Fisher exact test: $p=0.01 ; X^{2}=11.44 ; \mathrm{df}=2$ ). Dash (-) refers to no reported impacts. Percentages were based on the frequency each item was mentioned in thematically coded open questions.

\begin{tabular}{|c|c|c|c|}
\hline Land users' practices & $\begin{array}{c}\text { Community } \\
\text { members } \\
(\% ; n=30)\end{array}$ & $\begin{array}{c}\text { State reserve } \\
\text { managers } \\
(\% ; n=6)\end{array}$ & $\begin{array}{l}\text { Private reserve managers } \\
\qquad(\% ; n=4)\end{array}$ \\
\hline Do you control woody encroachment on your property? & 26 & 67 & 100 \\
\hline Do you control woody encroachment in your area? & 13 & - & - \\
\hline Management type: Maintain historic fire regime & - & 100 & 100 \\
\hline Manual clearing & 26 & - & 75 \\
\hline Fire storms (high intensity fires) & - & - & 25 \\
\hline Strategic area burns & - & - & 25 \\
\hline Mean cost of management? $(\mathrm{R} 1000=\sim$ US\$60) & $\begin{array}{c}\text { R367/yr } \\
\text {-/+ R378 (US\$25) }\end{array}$ & $\begin{array}{l}\mathrm{R} 163,000 / \mathrm{yr} \\
\text { (US\$11,000) }\end{array}$ & $\begin{array}{c}\mathrm{R} 293,751 / \mathrm{yr} \\
-/+\mathrm{R} 300,000(\mathrm{US} \$ 20,000)\end{array}$ \\
\hline
\end{tabular}

encroachment on account of anxiety about wild animals harming their crops, loss of arable land, and loss of landscape identity (Shackleton et al. 2013).

Our findings also point to interesting changes in perceptions over time. In a study done in the area a decade ago, the community cited increased removal of wood for building/firewood and browsing for animals as positive impacts of woody encroachment, and less grass for grazing and difficulty clearing land for cultivation as the main negative impacts (Wigley et al. 2009). Our study did not find prominent benefits of encroachment in terms of extra wood supply. Our interviews suggest that collection of firewood in the study area is declining because many households increasingly rely on electricity for their energy needs. According to StatsSA (2018), $92.3 \%$ of the area had electricity in 2011 as compared to $28.7 \%$ a decade earlier. Only two out of the 30 households in our survey still relied on firewood as their primary source of energy. Most households collected firewood only if there was a traditional/cultural ceremony taking place and large amounts of cooking needed to be done. The possible link between reduced firewood use and woody encroachment is important to note as the world aims to provide clean energy for everyone (Blair et al. 2018). Work by Russell and Ward (2014) suggested that declining firewood collection because of increased electrification of rural areas may be contributing to woodland expansion in traditional rangelands in South Africa. As electrification and urbanization continues in regions such as Hluhluwe where woody encroachment is prevalent, management and clearing strategies need to be in place to help land users manage the negative impacts of woody encroachment.

Impacts of woody encroachment on agricultural land also did not feature prominently in our findings, compared to the earlier work by Wigley et al. (2009). This is likely because many households ( $37 \%$, based on our interviews) have abandoned crop farming. Deagrarianization in the area is due to a combination of droughts of the past decade, new opportunities for employment in urban areas, changed value systems, and rural emigration (Shackleton et al. 2013). Deagrarianization in large parts of South Africa's rural areas has been linked to a significant increase in woody encroachment in abandoned cultivated fields (Shackleton et al. 2013, Hoffman 2014, Blair et al. 2018), and is likely to increase as rural emigration to urban areas continues (Christiaensen et al. 2013). Liao et al. (2020) warns that livelihood diversification, where the rural poor abandon farming and seek work in cities, does not necessarily translate into improved wellbeing, and may carry substantial risks of environmental degradation such as increased woody encroachment. As the threat of climate change looms, with increasing variability in droughts and floods, further deagrarianization in many rural areas of South Africa is likely to occur in the future, potentially leading to further woody encroachment if no interventions are put in place.

Our results indicate that, in contrast to community members, private game reserve managers were mainly concerned by impacts on their business through trees blocking guest's views of animals, reduction of grass for grazing by wildlife, and the high cost of clearing trees. Game visibility is an important factor for tourists returning to a game reserve (Gray and Bond 2013). In a survey of marketing strategies, beliefs, and practices of private game reserves in southern Africa, Buckley and Mossaz (2018) found that private game reserves prioritize marketing of game viewing opportunities, followed by luxury, exclusivity, and conservation. Woody encroachment negatively impacts tourism by changing the biodiversity of the area, because certain animals, e.g., cheetahs, white rhino, and certain bird species, need open areas to thrive (Maciejewski and Kerley 2014). This negatively impacts tourism because many guests, especially international tourists, mostly want to see mega-herbivores and large carnivores (Lindsey et al. 2007). Many private game reserves target international tourists from First World countries, and focus on having a few guests who pay high prices (Magole and Magole 2011). This likely explains why one of the reserves spent an estimated R650,000 (US\$43,000) on burning and manually clearing trees. Importantly, all clearing activities by reserves were focused on their own property and did not involve collaborative clearing initiatives with communities on adjoining land.

In contrast to community members and private reserve managers, the majority of the state game reserve managers thought woody encroachment was beneficial or had no impact on their business. Unlike private game reserves, the objectives of the state reserve center more exclusively on conservation. Consequently, they manage the landscape to maintain historic patterns and processes, using controlled burning to simulate natural fire patterns and maintain an open savanna ecosystem. However, Case and Staver (2017) examined woody encroachment across different fire frequencies in Hluhluwe-iMfolozi state reserve from 2007 to 2014 
and found that historic fire frequencies were no longer capable of mitigating woody encroachment in this reserve. The implications of this research have yet to be incorporated in management policies. Hluhluwe iMfolozi Game Reserve has a large number of elephants, which the managers are aware help control woody encroachment. Bark-stripping and uprooting of trees by elephants can result in mortality of adult trees and seedlings (O'Connor et al. 2007, 2014). Stevens et al. (2016) found that elephants had a significant impact on woody vegetation in low rainfall (MAP $<650 \mathrm{~mm}$ ) savannas compared to high rainfall areas. Given that Hluhluwe occurs in a high rainfall zone, this may explain the prevalence of woody encroachment despite the high number of elephants.

\section{CONCLUSION AND IMPLICATIONS FOR MANAGEMENT}

Savannas, which are widespread across the globe and account for $50 \%$ of the world's livestock farming, are subject to woody encroachment. Woody encroachment is a globally significant example of a regime shift with significant impacts on land users. Our results highlight how these impacts are differentiated across different land users, and the disproportionately negative impacts they may have on the rural poor. Given the high costs of combatting woody encroachment, our research highlights the need for state- or donor-funded support to manage woody encroachment to reduce the impacts experienced, especially by poor and marginalized communities.

In South Africa, much work and resources have gone into understanding the impacts of invasive alien species on different land users and clearing them through the state-funded Working for Water program (van Wilgen and Biggs 2011, Urgenson et al. 2013, Van Wilgen et al. 2014, Shackleton et al. 2015). Our research suggests that most land users would welcome a similar statesupported clearing program to combat woody encroachment. However, if similar clearing programs are to be developed to address woody encroachment, they must understand and align with land users' perceptions, values, and needs. Our results indicate that these perceptions, values, and needs may differ significantly among land users, which has implications for the design of policies and the potential for such policies to be supported by diverse local land users.

The multi-stakeholder approach adopted in this study highlights the value of taking a differentiated perspective in understanding the impacts of regime shifts. Our study underscores that not only the rural poor are negatively affected by woody encroachment and struggling to manage it. Private game reserves spend a lot of money on clearing trees and therefore would also benefit from a state tree clearing program and could potentially help fund such a program from their tourism revenue. These reserves also provide opportunities for doing research on the effectiveness of different clearing techniques. All the reserves in this study were trying different strategies to manage woody encroachment, but efficiency of these strategies is not being studied or published. For example, one private reserve has started experimenting with fire storms (high intensity fires) because historic fire frequencies are no longer enough to hold back woody encroachment (Crowlely et al. 2009). Involving multiple stakeholders in studies of the impacts of regime shifts is important for highlighting points of convergence and divergence between land users, facilitating learning, and helping reveal opportunities for intervention.
Finally, this study underscores the calls of other authors to be careful in applying the Food and Agriculture Organization's (FAO) definition of savanna, and for carbon emission projects to consider with more care where they implement these projects (Parr et al. 2014, Bond 2016, Bond et al. 2019). According to the FAO, landscapes with $>10 \%$ tree cover constitute forests, and therefore qualify for reforestation projects such as Reducing Emissions from Deforestation and Forest Degradation (REDD+) and other carbon emission reduction projects (Parr et al. 2014). Many of these projects target developing countries so that they can earn certified emission reduction credits that could be sold or traded to industrialized countries. Twenty-five percent of Africa would qualify for REDD+ projects if forests are defined as areas with $>10 \%$ tree cover (Parr et al. 2014). Many of these areas may naturally constitute savanna systems. Misclassification of savannas as degraded forests threatens the livelihoods of a large number of people who depend on these systems (Bond 2016), given that one-fifth of the global population, many of them poor, rely on grassy savannas for their livelihoods (Parr et al. 2014). If woody cover in these areas was expanded through ill-conceived reforestation programs it would have substantial social and ecological impacts (Veldman et al. 2015), as underscored by this study.

Responses to this article can be read online at: https://www.ecologyandsociety.org/issues/responses. php/12767

\section{Acknowledgments:}

We thank all the interviewees who generously shared their time and insights to participate in this study. We also would like to thank Dave Druce for his assistance in getting the project registered with Ezemvelo KZN Wildlife. Thanks to Ezemvelo KZN Wildlife-s Langelihle Gqosha for his help during the interviews. This paper draws on the PhD work of Linda Luvuno, which was funded by a Green Matter fellowship and an NRF scholarship linked to the South African Research Chair in Social-Ecological Systems and Resilience held by Prof Reinette (Oonsie) Biggs (grant 98766). Reinette Biggs was co-funded by the same NRF grant and a Young Researchers grant from the Vetenskapsrådet in Sweden (grant 621-2014-5137). Nicola Stevens was funded by the National Research Foundation grants ACYS (114695).

\section{Data Availability:}

The data that support the findings of this study are available on request from the corresponding author, L. B. Luvuno. The data are not publicly available because they contain information that could compromise the privacy of the interviewees. Ethical approval was granted by Stellenbosch University (CEE-2017-0200-247).

\section{LITERATURE CITED}

Alhojailan, M. I. 2012. Thematic analysis: a critical review of its process and evaluation. West East Journal of Social Sciences 1 (1):39-47. [online] URL: https://faculty.ksu.edu.sa/sites/default/ files/ta thematic analysis $\mathrm{dr}$ mohammed alhojailan.pdf 
Anadón, J. D., O. E. Sala, B. L. Turner II, and E. M. Bennett. 2014. Effect of woody-plant encroachment on livestock production in North and South America. Proceedings of the National Academy of Sciences 111(35):12948-12953. https://doi. org/10.1073/pnas.1320585111

Archer, S. R., and K. I. Predick. 2014. An ecosystem services perspective on brush management: research priorities for competing land-use objectives. Journal of Ecology 102 (6):1394-1407. https://doi.org/10.1111/1365-2745.12314

Aylward, B., and E. Lutz. 2003. Nature tourism, conservation, and development in KwaZulu-Natal, South Africa. World Bank Publications, Washington, D.C., USA. [online] URL: http://hdl. handle.net/10986/15180

Biggs, R., G. D. Peterson, and J. C. Rocha. 2018. The regime shifts database: a framework for analyzing regime shifts in socialecological systems. Ecology and Society 23(3):9. https://doi. org/10.5751/ES-10264-230309

Blair, D., C. M. Shackleton, and P. J. Mograbi. 2018. Cropland abandonment in South African smallholder communal lands: land cover change (1950-2010) and farmer perceptions of contributing factors. Land 7(4):121. https://doi.org/10.3390/ land7040121

Bond, W. J. 2016. Ancient grasslands at risk. Science 351 (6269):120-122. https://doi.org/10.1126/science.aad5132

Bond, W. J., N. Stevens, G. F. Midgley, and C. E. R. Lehmann. 2019. The trouble with trees: afforestation plans for Africa. Trends in Ecology \& Evolution 34(11):963-965. https://doi.org/10.1016/ j.tree.2019.08.003

Bree, R. T., and G. Gallagher. 2016. Using Microsoft Excel to code and thematically analyse qualitative data: a simple, costeffective approach. All Ireland Journal of Higher Education 8(2). [online] URL: https://ojs.aishe.org/index.php/aishe-j/article/ view/281

Briggs, J. M., A. K. Knapp, J. M. Blair, J. L. Heisler, G. A. Hoch, M. S. Lett, and J. K. McCarron. 2005. An ecosystem in transition: causes and consequences of the conversion of mesic grassland to shrubland. BioScience 55(3):243-254. https://doi.org/10.1641/0006-3568 (2005)055[0243:AEITCA]2.0.CO;2

Buckley, R., and A. Mossaz. 2018. Private conservation funding from wildlife tourism enterprises in sub-Saharan Africa: conservation marketing beliefs and practices. Biological Conservation 218:57-63. https://doi.org/10.1016/j.biocon.2017.12.001

Cardinale, B. J., J. E. Duffy, A. Gonzalez, D. U. Hooper, C. Perrings, P. Venail, A. Narwani, G. M. Mace, D. Tilman, D. Wardle, A. P. Kinzig, G. C. Daily, M. Loreau, J. B. Grace, A. Larigauderie, D. S. Srivastava, and S. Naeem. 2012. Biodiversity loss and its impact on humanity. Nature 486:59-67. https://doi. org/10.1038/nature 11148

Carpenter, S. R., H. Mooney, J. Agard, D. Capistrano, R. S. Defries, S. Díaz, T. Dietz, A. K. Duraiappah, A. Oteng-Yeboah, H. M. Pereira, C. Perrings, W. V. Reid, J. Sarukhan, R. J. Scholes, and A. Whyte. 2009. Science for managing ecosystem services: beyond the Millennium Ecosystem Assessment. Proceedings of the National Academy of Sciences 106(5):1305-1312. https://doi. org/10.1073/pnas.0808772106
Case, M. F., and A. C. Staver. 2017. Fire prevents woody encroachment only at higher-than-historical frequencies in a South African savanna. Journal of Applied Ecology 54 (3):955-962. https://doi.org/10.1111/1365-2664.12805

Christiaensen, L., J. De Weerdt, and Y. Todo. 2013. Urbanization and poverty reduction: the role of rural diversification and secondary towns. Agricultural Economics 44(4-5):435-447. https://doi.org/10.1111/agec.12028

Crowlely, G., S. Garnett, and S. Shepard. 2009. Impact of stormburning on Melaleuca viridiflora invasion of grasslands and grassy woodlands on Cape York Peninsula, Australia. Austral Ecology 34(2):196-209. https://doi.org/10.1111/j.1442-9993.2008.01921. $\underline{x}$

Dai, J., L. Li, S. Kim, B. Kimball, S. M. Jazwinski, and J. Arnold. 2007. Exact sample size needed to detect dependence in $2 \times 2 \times$ 2 tables. Biometrics 63(4):1245-1252. https://doi.org/10.1111/ j.1541-0420.2007.00801.X

Daskin, J. H., M. Stalmans, and R. M. Pringle. 2016. Ecological legacies of civil war: 35-year increase in savanna tree cover following wholesale large-mammal declines. Journal of Ecology 104(1):79-89. https://doi.org/10.1111/1365-2745.12483

Daw, T. M., S. Coulthard, W. W. L. Cheung, K. Brown, C. Abunge, D. Galafassi, G. D. Peterson, T. R. Mcclanahan, J. O. Omukoto, and L. Munyi. 2015. Evaluating taboo trade-offs in ecosystems services and human well-being. Proceedings of the National Academy of Sciences 112(22):6949-6954. https://doi.org/10.1073/ pnas. 1414900112

Díaz, S., J. G. Hodgson, K. Thompson, M. Cabido, J. H. C. Cornelissen, A. Jalili, G. Montserrat-Martí, J. P. Grime, F. Zarrinkamar, Y. Asri, S. R. Band, S. Basconcelo, P. Castro-Díez, G. Funes, B. Hamzehee, M. Khoshnevi, N. Pérez-Harguindeguy, M. C. Pérez-Rontomé, A. Shirvany, F. Vendramini, S. Yazdani, R. Abbas-Azimi, A. Bogaard, S. Boustani, M. Charles, M. Dehghan, L. de Torres-Espuny, V. Falczuk, J. Guerrero-Campo, A. Hynd, G. Jones, E. Kowsary, F. Kazemi-Saeed, M. MaestroMartínez, A. Romo-Díez, S. Shaw, B. Siavash, P. Villar-Salvador, and M. R. Zak. 2004. The plant traits that drive ecosystems: evidence from three continents. Journal of Vegetation Science 15 (3):295-304. https://doi.org/10.1111/j.1654-1103.2004.tb02266.X

Eldridge, D. J., M. A. Bowker, F. T. Maestre, E. Roger, J. F. Reynolds, and W. G. Whitford. 2011. Impacts of shrub encroachment on ecosystem structure and functioning: towards a global synthesis. Ecology Letters 14(7):709-22. https://doi. org/10.1111/j.1461-0248.2011.01630.x

Ellis, E. C., U. Pascual, and O. Mertz. 2019. Ecosystem services and nature's contribution to people: negotiating diverse values and trade-offs in land systems. Current Opinion in Environmental Sustainability 38:86-94. https://doi.org/10.1016/j.cosust.2019.05.001

Gray, E. F., and W. J. Bond. 2013. Will woody plant encroachment impact the visitor experience and economy of conservation areas? Koedoe 55(1):1-9. https://doi.org/10.4102/koedoe.v55i1.1106

Grossman, J. J. 2015. Ecosystem service trade-offs and land use among smallholder farmers in eastern Paraguay. Ecology and Society 20(1):19. https://doi.org/10.5751/ES-06953-200119 
Hamann, M., R. Biggs, and B. Reyers. 2015. Mapping socialecological systems: identifying 'green-loop' and 'red-loop' dynamics based on characteristic bundles of ecosystem service use. Global Environmental Change 34:218-226. https://doi. org/10.1016/j.gloenvcha.2015.07.008

Higgins, S. I., C. M. Shackleton, and E. R. Robinson. 1999. Changes in woody community structure and composition under contrasting landuse systems in a semi. Journal of Biogeography 26(3):619-627. [online] URL: https://www.jstor.org/stable/2656147

Hoffman, M. T. 2014. Changing patterns of rural land use and land cover in South Africa and their implications for land reform. Journal of Southern African Studies 40(4):707-725. https://doi. org/10.1080/03057070.2014.943525

Honda, E. A., and G. Durigan. 2016. Woody encroachment and its consequences on hydrological processes in the savannah. Philosophical Transactions of the Royal Society B: Biological Sciences 371(1703):115-133. https://doi.org/10.1098/rstb.2015.0313

Huxman, T. E., B. P. Wilcox, D. D. Breshears, R. L. Scott, K. A. Snyder, E. E. Small, K. Hultine, W. T. Pockman, and R. B. Jackson. 2005. Ecohydrological implications of woody encroachment. Ecology 86(2):308-319. https://doi.org/10.1890/03-0583

King, E., J. Cavender-Bares, P. Balvanera, T. H. Mwampamba, and S. Polasky. 2015. Trade-offs in ecosystem services and varying stakeholder preferences: evaluating conflicts, obstacles, and opportunities. Ecology and Society 20(3):25. https://doi. org/10.5751/ES-07822-200325

Kok, P., and M. Collinson. 2006. Migration and urbanization in South Africa. Statistics South Africa, Pretoria, South Africa. [online] URL: http://www.statssa.gov.za/publications/Report-03-04-02/ Report-03-04-02.pdf

Lawes, M. J., D. M. Macfarlane, and H. A. C. Eeley. 2004. Forest landscape pattern in the KwaZulu-Natal midlands, South Africa: 50 years of change or stasis? Austral Ecology 29(6):613-623. https://doi.org/10.1111/j.1442-9993.2004.01396.x

Lehmann, C. E. R., T. M. Anderson, M. Sankaran, S. I. Higgins, S. Archibald, W. A. Hoffmann, N. P. Hanan, R. J. Williams, R. J. Fensham, J. Felfili, L. B. Hutley, J. Ratnam, J. San Jose, R. Montes, D. Franklin, J. Russell-Smith, C. M. Ryan, G. Durigan, P. Hiernaux, R. Haidar, D. M. J. S. Bowman, and W. J. Bond. 2014. Savanna vegetation-fire-climate relationships differ among continents. Science 343(6170):548-552. https://doi.org/10.1126/ science. 1247355

Leslie, P., and J. T. McCabe. 2013. Response diversity and resilience in social-ecological systems. Current Anthropology 54 (2):114-143. https://doi.org/10.1086/669563

Liao, C., A. Agrawal, P. E. Clark, S. A. Levin, and D. I. Rubenstein. 2020. Landscape sustainability science in the drylands: mobility, rangelands and livelihoods. Landscape Ecology 35(11):2433-2447. https://doi.org/10.1007/s10980-020-01068-8

Lindsey, P. A., R. Alexander, M. G. L. Mills, S. Romañach, and R. Woodroffe. 2007. Wildlife viewing preferences of visitors to protected areas in South Africa: implications for the role of ecotourism in conservation. Journal of Ecotourism 6(1):19-33. https://doi.org/10.2167/joe133.0

Loreau, M., S. Naeem, P. Inchausti, J. Bengtsson, J. P. Grime, A. Hector, D. U. Hooper, M. A. Huston, D. Raffaelli, B. Schmid, D. Tilman, and D. A. Wardle. 2001. Biodiversity and ecosystem functioning: current knowledge and future challenges. Science 294(5543):804-808. https://doi.org/10.1126/science.1064088

Luvuno, L., R. Biggs, N. Stevens, and K. Esler. 2018. Woody encroachment as a social-ecological regime shift. Sustainability 10(7):2221. https://doi.org/10.3390/su10072221

Maciejewski, K., and G. I. H. Kerley. 2014. Understanding tourists' preference for mammal species in private protected areas: is there a case for extralimital species for ecotourism? PLOS ONE 9(2):e88192 https://doi.org/10.1371/journal.pone.0088192

Magole, L. I., and L. Magole. 2011. Revisiting Botswana's highvalue, low-volume tourism. Tourism Analysis 16(2):203-210. https://doi.org/10.3727/108354211X13014081270486

McNally, C. G., A. J. Gold, R. B. Pollnac, and H. R. Kiwango. 2016. Stakeholder perceptions of ecosystem services of the Wami River and estuary. Ecology and Society 21(3):34. https://doi. org/10.5751/ES-08611-210334

Menzel, S., and J. Teng. 2009. Ecosystem services as a stakeholderdriven concept for conservation science. Conservation Biology 24 (3):907-909. https://doi.org/10.1111/j.1523-1739.2009.01347.x

Millennium Ecosystem Assessment. 2005. Ecosystems and human well-being: synthesis. Island, Washington, D.C., USA. [online] URL: https://www.millenniumassessment.org/documents/ document.356.aspx.pdf

Moustakas, A., K. Wiegand, K. M. Meyer, D. Ward, and M. Sankaran. 2010. Learning new tricks from old trees: revisiting the savanna question. Frontiers of Biogeography 2(2):47-53. https:// doi.org/10.21425/F5FBG12335

Mugasi, S. K., E. N. Sabiiti, and B. M. Tayebwa. 2000. The economic implications of bush encroachment on livestock farming in rangelands of Uganda. African Journal of Range \& Forage Science 17(1-3):64-69. https://doi.org/10.2989/10220110009485741

O'Connor, T. G., P. S. Goodman, and B. Clegg. 2007. A functional hypothesis of the threat of local extirpation of woody plant species by elephant in Africa. Biological Conservation 136 (3):329-345. https://doi.org/10.1016/j.biocon.2006.12.014

O’Connor, T. G., J. R. Puttick, and M. T. Hoffman. 2014. Bush encroachment in southern Africa: changes and causes. African Journal of Range \& Forage Science 31:67-88. https://doi. org/10.2989/10220119.2014.939996

Parr, C. L., C. E. R. Lehmann, W. J. Bond, W. A. Hoffmann, and A. N. Andersen. 2014. Tropical grassy biomes: misunderstood, neglected, and under threat. Trends in Ecology \& Evolution 29 (4):205-213. https://doi.org/10.1016/j.tree.2014.02.004

Reid, W. V., D. Chen, L. Goldfarb, H. Hackmann, Y. T. Lee, K. Mokhele, E. Ostrom, K. Raivio, J. Rockstrom, H. J. Schellnhuber, and A. Whyte. 2010. Earth system science for global sustainability: grand challenges. Science 330(6006):916-917. https://doi.org/10.1126/science.1196263 
Russell, J. M., and D. Ward. 2014. Remote sensing provides a progressive record of vegetation change in northern KwaZuluNatal, South Africa, from 1944 to 2005. International Journal of Remote Sensing 35(3):904-926. https://doi.org/10.1080/0143116$\underline{1.2013 .873154}$

Sankaran, M., N. P. Hanan, R. J. Scholes, J. Ratnam, D. J. Augustine, B. S. Cade, J. Gignoux, S. I. Higgins, X. Le Roux, F. Ludwig, J. Ardo, F. Banyikwa, A. Bronn, G. Bucini, K. K. Caylor, M. B. Coughenour, A. Diouf, W. Ekaya, C. J. Feral, E. C. February, P. G. H. Frost, P. Hiernaux, H. Hrabar, K. L. Metzger, H. H. T. Prins, S. Ringrose, W. Sea, J. Tews, J. Worden, and N. Zambatis. 2005. Determinants of woody cover in African savannas. Nature 438:846-9. https://doi.org/10.1038/nature04070

Scheffer, M., S. Carpenter, J. A. Foley, C. Folke, and B. Walker. 2001. Catastrophic shifts in ecosystems. Nature 413:591-596. https://doi.org/10.1038/35098000

Shackleton, C., S. Shackleton, T. Netshiluvhi, and F. Mathabela. 2005. The contribution and direct-use value of livestock to rural livelihoods in the Sand River catchment, South Africa. African Journal of Range \& Forage Science 22(2):127-140. https://doi. org/10.2989/10220110509485870

Shackleton, R., C. Shackleton, S. Shackleton, and J. Gambiza. 2013. Deagrarianisation and forest revegetation in a biodiversity hotspot on the Wild Coast, South Africa. PLoS ONE 8(10): e76939. https://doi.org/10.1371/journal.pone.0076939

Shackleton, R. T., D. C. Le Maitre, and D. M. Richardson. 2015. Stakeholder perceptions and practices regarding Prosopis (mesquite) invasions and management in South Africa. Ambio 44:569-581. https://doi.org/10.1007/s13280-014-0597-5

Skowno, A. L., M. W. Thompson, J. Hiestermann, B. Ripley, A. G. West, and W. J. Bond. 2017. Woodland expansion in South African grassy biomes based on satellite observations (1990-2013): general patterns and potential drivers. Global Change Biology 23(6):2358-2369. https://doi.org/10.1111/ gcb. 13529

Statistics South Africa (StatsSA). 2018. General household survey 2018. Statistics South Africa, Pretoria, South Africa. [online] URL: https://www.statssa.gov.za/publications/P0318/ P03182018.pdf

Stevens, N., B. F. N. Erasmus, S. Archibald, and W. J. Bond. 2016. Woody encroachment over 70 years in South African savannahs: overgrazing, global change or extinction aftershock? Philosophical Transactions of the Royal Society B: Biological Sciences 371(1703). https://doi.org/10.1098/rstb.2015.0437

Stevens, N., C. E. R. Lehmann, B. P. Murphy, and G. Durigan. 2017. Savanna woody encroachment is widespread across three continents. Global Change Biology 23(1):235-244. https://doi. org/10.1111/gcb.13409

Thondhlana, G., P. Vedeld, and S. Shackleton. 2012. Natural resource use, income and dependence among San and Mier communities bordering Kgalagadi Transfrontier Park, southern Kalahari, South Africa. International Journal of Sustainable Development \& World Ecology 19(5):460-470. https://doi. org/10.1080/13504509.2012.708908
Troell, M., L. Pihl, P. Rönnbäck, H. Wennhage, T. Söderqvist, and N. Kautsky. 2005. Regime shifts and ecosystem services in Swedish coastal soft bottom habitats: when resilience is undesirable. Ecology and Society 10(1):30. https://doi. org/10.5751/ES-01374-100130

Twine, W., D. Moshe, T. Netshiluvhi, and V. Siphugu. 2003. Consumption and direct-use values of savanna bio-resources used by rural households in Mametja, a semi-arid area of Limpopo province, South Africa. South African Journal of Science 99:467-473. [online] URL: https://researchspace.csir.co.za/ dspace/bitstream/handle/10204/1903/twine 2003.pdf

Urgenson, L. S., H. E. Prozesky, and K. J. Esler. 2013. Stakeholder perceptions of an ecosystem services approach to clearing invasive alien plants on private land. Ecology and Society 18(1):26. https:// doi.org/10.5751/ES-05259-180126

van Wilgen, B. W., and H. C. Biggs. 2011. A critical assessment of adaptive ecosystem management in a large savanna protected area in South Africa. Biological Conservation 144(4):1179-1187. https://doi.org/10.1016/j.biocon.2010.05.006

van Wilgen, B. W., S. J. Davies, and D. M. Richardson. 2014. Invasion science for society: a decade of contributions from the centre for invasion biology. South African Journal of Science 110 (7/8):12. https://doi.org/10.1590/sajs.2014/a0074

Veldman, J. W., E. Buisson, G. Durigan, G. W. Fernandes, S. Le Stradic, G. Mahy, D. Negreiros, G. E. Overbeck, R. G. Veldman, N. P. Zaloumis, F. E. Putz, and W. J. Bond. 2015. Toward an oldgrowth concept for grasslands, savannas, and woodlands. Frontiers in Ecology and the Environment 13(3):154-162. https:// doi.org/10.1890/140270

Wangai, P. W., B. Burkhard, and F. Müller. 2016. A review of studies on ecosystem services in Africa. International Journal of Sustainable Built Environment 5(2):225-245. https://doi. org/10.1016/j.ijsbe.2016.08.005

Wigley, B. J., W. J. Bond, and M. T. Hoffman. 2009. Bush encroachment under three contrasting land-use practices in a mesic South African savanna. African Journal of Ecology 47 (1):62-70. https://doi.org/10.1111/j.1365-2028.2008.01051.x

Wigley, B. J., W. J. Bond, and M. T. Hoffman. 2010. Thicket expansion in a South African savanna under divergent land use: local vs. global drivers? Global Change Biology 16(3):964-976. https://doi.org/10.1111/j.1365-2486.2009.02030.x

Wilcox, B. P., A. Birt, S. R. Archer, S. D. Fuhlendorf, U. P. Kreuter, M. G. Sorice, W. J. D. van Leeuwen, and C. B. Zou. 2018. Viewing woody-plant encroachment through a social-ecological lens. BioScience 68(9):691-705. https://doi.org/10.1093/biosci/biy051

Ye, Y., B. A. Bryan, J. Zhang, J. D. Connor, L. Chen, Z. Qin, and M. He. 2018. Changes in land-use and ecosystem services in the Guangzhou-Foshan Metropolitan Area, China from 1990 to 2010: implications for sustainability under rapid urbanization. Ecological Indicators 93:930-941. https://doi.org/10.1016/j. ecolind.2018.05.031 
Appendix 1: Questionnaire used for community members
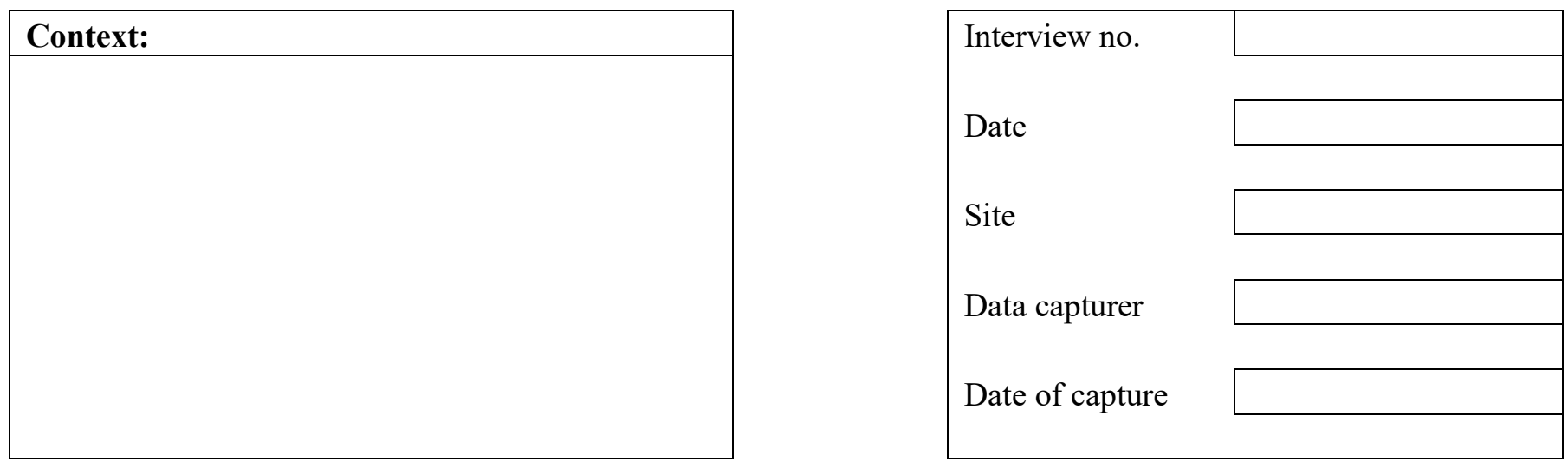

\section{Part A: Biographic details}

\begin{tabular}{|c|c|c|c|}
\hline Land use type & L.C & C.F & G.R \\
\hline \multicolumn{4}{|l|}{ Age } \\
\hline \multicolumn{4}{|l|}{$\mathrm{F} / \mathrm{M}$} \\
\hline \multicolumn{4}{|l|}{ Race: } \\
\hline Owner & Renting & & Rent Free \\
\hline \multicolumn{4}{|l|}{$\begin{array}{l}\text { No. of people in } \\
\text { household }\end{array}$} \\
\hline $\begin{array}{l}\text { Where are you } \\
\text { from? }\end{array}$ & & & \\
\hline
\end{tabular}

\begin{tabular}{|l|l|}
\hline Education \\
\hline Some PS & \\
\hline Completed PS & \\
\hline Some HS & \\
\hline Matriculated & \\
\hline Higher & \\
Education & \\
\hline Post & \\
Graduate & \\
\hline
\end{tabular}

\section{Notes}

1. Number of wage earners in household

2. Job Types of wage earners

3. Number of pension holders

4. Number of other grant holders

5. Are there family members who live in the city during the week or certain months who contribute to the household income?

6 . How long have you lived in this location 


\section{Section B}

\section{Livestock ownership}

7. Do you keep any livestock? [Yes] [No]

8. What type of livestock? [cattle] [sheep] [goats] [other]

9. How many units? Cattle___ Sheep___ Goats___ Other

10. What is the main reason for keeping livestock?

11. Has this changed over the past 20 years? [Yes] [No]

12. How has it changed?

13. When did you make those changes and why did you make those changes?

14. Has your ability to take care of your livestock changed over time? [Yes] [No]

15. How?

16. Has your sense of personal and household security changed over time? [Yes] [No]

17. Has your ability to feed and manage your household changed over time? [Yes] [No]

18. Can you have examples to share with me?

\section{Section C}

\section{Knowledge and Perceptions of the landscape}

19. How has the number of trees changed in the landscape over the last 20 years?

How? [Increased] [Decreased] [Remained Constant]

20. Do you think it is a problem? [Yes] [No] [Neither] [Both]

21. Do you have trees on your property? [Yes] [No] [Not sure]

22. Were these trees planted? [Yes] [No] [Not sure]

23. How many trees do you have on the property [0-5] [6-10] [11-20] [20-40] [>40] on your property? 
24. Are trees spreading on your property? [Yes] [No] [Not sure]

25. Are trees spreading in the area? [Yes] [No] [Not sure]

26. How has the spreading of the trees impacted you and your livelihood?

27. Please explain

28. Has the use of grass for grazing for your livestock changed over the years? [Yes] [No] [Not sure]

29. If so, how?

30. Has the use of water for you or your livestock changed over the years? [Yes] [No] [Not sure]

31. Do you have piped water on the property [Yes] [No]

32. Do you collect from elsewhere? [Yes] [No]

33. Do you plant any crops on your property? [Yes] [No]

34. Why?

35. Has anything changed in how you use your property? [Yes] [No]

36. How?

37. Has anything else changed in how you use the landscape? [Yes] [No]

38. How?

\section{Section D}

\section{Uses of the trees and natural resources}

39. Does your household harvest trees or any other resources? [Yes] [No] [Not Sure]

40. What do you harvest these resources for?

\begin{tabular}{|l|l|l|l|l|l|}
\hline Use & Own Use? & Quantity/month & Sale? & Quantity/month & $\begin{array}{l}\text { Collection } \\
\text { Point }\end{array}$ \\
\hline Fuelwood & & & & & \\
\hline Fodder & & & & & \\
\hline
\end{tabular}




\begin{tabular}{|l|l|l|l|l|l|}
\hline $\begin{array}{l}\text { Building } \\
\text { Material }\end{array}$ & & & & & \\
\hline Furniture & & & & & \\
\hline Food & & & & & \\
\hline Medicine & & & & & \\
\hline Utensils & & & & & \\
\hline Mats/ivovo & & & & & \\
\hline Decorations & & & & & \\
\hline Thatch & & & & & \\
\hline Other & & & & & \\
\hline
\end{tabular}

41. Has this changed over time?

42. How?

43. Do trees also provide other non-direct use benefits? [Yes] [No]

44. What?

45. Does it cost you anything to harvest the trees? [Yes] [No]

46. How much (money \&/or time)?

47. Do you sell the wood? [Yes] [No] [Not Sure]

48. How many hours a week do you harvest?

49. Do you employ someone to help you? [Yes] [No]

50. How many people?

51. Has your use of trees [Increased] [Remained Constant] [Decreased] over the last 15-20?

52. Why?

53. Do you do anything to try and counter the change? 
54. What do you think is the main cause of the increased trees in the landscape and why?

55. What management strategy do you apply on the property?

56. Do you have any further input or bush encroachment impacts not discussed in the interview you would like to add? 


\section{Appendix 2: Questionnaire used for game reserve managers}

\section{Part A: Biographic details}

\begin{tabular}{|l|l|}
\hline Land use type & \\
\hline Age & \\
\hline F/M & \\
\hline Race: & \\
\hline Education level & \\
\hline How long have you worked here? & \\
\hline
\end{tabular}

\section{Part B: Knowledge and Perceptions of the landscape}

1. Has there been major changes in the landscape that you've noticed? [Yes] [No]

2. Are there more trees in the landscape? [Yes] [No] [Not sure]

3. Do you think it's a problem? [Yes] [No] [Not sure]

4.

5. Are they [Very Common] [Common] [Moderate] [Scarce] [Very Scarce] on your reserve?

6. Are trees spreading on your reserve? [Yes] [No]

7. Are trees spreading in the general area? [Yes] [No]

8. Are the trees [Beneficial] [Harmful] [No Impact] for the business and the way you manage the reserve?

9. Please explain

10. Has the use of grass for grazing and water for your game changed over the years? [Yes] [No]

11. If so, how?

12. Do you clear-fell? [Yes] [No]

13. Does it cost you anything to clear the trees? [Yes] [No]

14. How much (money \&/or time)?

15. If you sell the wood, where do you sell it? 
16. How many hours a week do you harvest?

17. Do you employ someone to help you? [Yes] [No]

18. How many people?

19. Has the reserve's use of trees [Increased] [Remained Constant] [Decreased] over the last 10-20?

20. Why?

21. Do you have any other bush management strategies?

22. What does that cost in both time and money?

23. How often do you have to do this?

24. What do you think is the main cause of the increased trees in the landscape?

25. Why do you think so?

26. What management strategy do you apply on the property?

27. Has it been a successful strategy or do you think it would be beneficial to do something else? 
28. Do you have any further input or bush encroachment impacts not discussed in the interview you would like to add? 